\title{
ע Äidin vanhemmuustyylin ja vanhemmuuden stressin ja vanhempien nukuttamistyylin yhteys kahdeksan kuukauden ikäisen lapsen univaikeuksiin
}

\begin{abstract}
Tässä tutkimuksessa tarkasteltiin perheympäristöä kuvaavien tekijöiden, äidin vanhemmuuden stressin, äidin vanhemmuustyylin ja vanhempien nukuttamistyylin sekä kahdeksan kuukauden ikäisen lapsen univaikeuksien välistä yhteyttä. Aineistona käytettiin Lapsen uni ja terveys -tutkimushankkeessa kerättyä kyselyaineistoa. Tutkimushankkeessa kerätään pitkittäisaineistoa vuonna 2011 ja vuonna 2012 syntyvien lasten vanhemmilta. Hanke on toteutettu Pirkanmaan sairaanhoitopiirin alueella. Tässä tutkimuksessa käytettiïn aineistoa, joka oli kerätty raskausaikana $(n=1667)$ ja lapsen ollessa kahdeksan kuukauden ikäinen (äitien $n=1289$ ja lasten $n=1294)$. Analyysimenetelminä käytettiiin logistista ja lineaarista regressioanalyysia. Tulosten perusteella lapsen univaikeuksiin olivat yhteydessä äidin kokema vanhemmuuden stressi, korkeampi koulutus, sekä vanhemman käyttämät aktiiviset ja passïviset fyysiset nukuttamistyylit.
\end{abstract}

ASIASANAT: lapsen uni, vanhemmuustyyli, nukuttamistyyli, vanhemmuuden stressi NIINA HÄKÄLÄ, PIRJO PÖLKKI, JUHA HÄMÄLÄINEN, TIINA PAUNIO, ANNELI KYLLIÄINEN, OUTI SAARENPÄÄ-HEIKKILÄ, JUULIA PAAVONEN

\section{JOHDANTO}

Pienen lapsen uniongelmat koskettavat monia suomalaisia perheitä, vaikkakaan aivan pienten lasten uniongelmien yleisyydestä Suomessa ei ole tutkimustuloksia. Kuitenkin noin seitsemän prosenttia 8-9-vuotiaista lapsista on havaittu kärsivän häiriintyneestä unesta (sekä vanhempien että lapsen itsensä raportoimana) (1), ja yksitoista prosenttia suomalaisnuorista raportoi kärsivänsä jokailtaisista tai usein toistuvista yöheräilyistä tai nukahtamisvaikeuksista (2). Pienillä lapsilla uniongelmia voi olla vielä tätäkin enemmän; kansainvälisissä tutkimuksissa on arvioitu, että jopa 25-50 prosenttia 6-12 kuukauden ikäisistä lapsista kärsii yöheräilyistä tai nukahtamisvaikeuksista (3). Unen merkitystä pienelle lapselle ei voi aliarvioida. On havaittu, että fyysinen kasvu ja useat erilaiset terveyteen liittyvät ongelmat liittyvät uneen (4). Pienten lasten uniongelmista kärsivät myös vanhemmat ja muut perheenjäsenet: lapsen uniongelmien seurauksena vanhempien oma uni on riittämätöntä, minkä seurauksena he stressaantuvat (5), sekä jopa ahdistuvat (6) ja masentuvat (7). Pahimmillaan lapsen uniongelmat voivat johtaa lapsen kaltoinkohteluun (8).

Vaikka uni on homeostaattisen ja sirkadiaanisen järjestelmän säätelemää (9) biologista ja geneettistäkin käyttäytymistä, ei psykososiaalisen ja kulttuurisen ympäristön merkitystä voi olla huomioimatta. Vallitsevat tavat ja kulttuuri vaikuttavat vahvasti siihen, missä ja miten lapsen oletetaan nukkuvan ja mitä pidetään normaalina nukkumisena. Näkemykset unen ongelmallisuudesta vaihtelevat kulttuureittain merkittävästi $(10,11,12)$. Esimerkkinä kulttuurien välisistä eroista on suhtautuminen lapsen ja vanhemman yhdessä nukkumiseen (engl. co-sleeping). Toisissa kulttuureissa sitä pidetään normina, ja toisissa taas erillään nukkuminen on vallitseva käytäntö (12). 
Psykososiaalinen ympäristö sisältää erilaisia riski- ja suojatekijöitä, joiden tiedetään vaikuttavan unen laatuun ja uniongelmien syntymiseen. Etenkin pikkuvauvoilla nukkumista on käsiteltävä lapsen ja hänen huoltajansa välisen suhteen ja vuorovaikutuksen kontekstissa (3). Lapsi kehittyy ja on vuorovaikutuksessa ympäristönsä kanssa niin kutsuttujen proksimaalisten prosessien eli lähiprosessien (13) kautta ja yhteys ei ole pelkästään yksisuuntainen ympäristöstä lapseen, vaan myös toisinpäin. Lähiprosessit toimivat erityisesti lapsen ja hänen mikroympäristönsä välillä. Mikroympäristö tarkoittaa pienillä lapsilla yleensä lapsen perhettä. Tähän tutkimukseen on valittu lapsen mikroympäristön eli perheympäristön tekijöistä äidin vanhemmuustyyli, äidin kokema vanhemmuuden stressi ja vanhempien nukuttamistyyli.

Vanhemmuustyylit voidaan määritellä joukoksi vanhemman lapseen kohdistamia asenteita ja uskomuksia, jotka välittyvät lapselle vanhemman käytöksen kautta ja ovat pohjana tilannekohtaisemmille kasvatuskäytännöille (14). On havaittu, että vanhemmuustyylillä on suuri merkitys lapsen varhaiseen sosioemotionaaliseen kehitykseen (15). Sen sijaan vanhemmuustyylin ja lapsen unen välisestä yhteydestä ei juurikaan ole tutkimusta, ja tiedossamme olevat tutkimukset ovat keskittyneet pääasiassa hieman tutkimaan hieman vanhempia lapsia. Näiden tutkimusten tulokset ovat osin ristiriitaisia. Tämä voi johtua esimerkiksi siitä, että vanhemmuustyyliä on käsitteellistetty tutkimuksissa monin eri tavoin. Scher ja Blumberg (16) tutkivat vanhemmuustyylin ja 1-vuotiaiden lasten yöheräilyjen yhteyttä. Tutkimuksessa käytettiin jaottelua fasilitaattori- (facilitator) tai regulaattoriryhmiin (regulator) sen mukaan, millainen orientaatio äidillä on lastaan ja äitiyden roolia kohtaan (17 sit. 16). Fasilitaattori-äidit kokivat, että ympäristön tulee mukautua lapsen tarpeisiin, kun taas regulaattori-äidit olivat sitä mieltä, että vauvan tulee sopeutua ympäristöönsä (16). Tutkimuksen mukaan yöheräily oli tavallisempaa niillä lapsilla, joiden äidit kuuluivat regulaattori-ryhmään, vaikka syytä tälle yhteydelle ei löydetty. Scherin (18) myöhempi tutkimus vahvisti tätä tutkimustulosta.

Chou ym. (19) havaitsivat, että äidin ylisuojeleva vanhemmuustyyli oli yhteydessä uniongelmiin (toistuvat yöheräilyt ja uni-valverytmin häi- riöt) autistisilla lapsilla. Ylisuojelevan tyylin on havaittu olevan yhteydessä myös lapsen muihin kehityksellisiin ongelmiin, kuten ahdistukseen (20). Sen sijaan Chou ym. (19) eivät löytäneet yhteyttä hellän ja rakastavan tai autoritaarisen ja kontrolloivan vanhemmuustyylin ja lapsen nukkumisen välillä, vaikka muissa tutkimuksissa niiden välisestä yhteydestä on viitteitä. Negatiivisessa mielessä kontrolloivan vanhemmuustyylin on havaittu olevan yhteydessä lyhyempään yöunen kestoon alakouluikäisillä lapsilla (21). On havaittu, että vanhempien lasten unen riskitekijänä voi olla vanhemman salliva ja rento vanhemmuustyyli (22, 23 sit. 24), kun taas aktiivinen, auktoritatiivinen ja jämäkkä vanhemmuustyyli voi toimia unta suojaavana tekijänä $(24,25)$. Yhteys voi johtua siitä, että salliva ja rento vanhempi antaa lapsen liiaksi itse päättää nukkumaanmenoajoistaan, jolloin unirytmi ei ole sopiva. Aktiivinen vanhempi taas kannustaa lastaan noudattamaan tiettyjä nukkumaanmenorituaaleja, joilla on positiivisia vaikutuksia uneen (24).

Vanhemmuustyylin ja lapsen unen yhteyttä huomattavasti enemmän on tutkittu vanhempien käyttämien rauhoittelu- ja nukuttamistyylien yhteyksiä lapsen uneen, erityisesti pienten lasten kohdalla. Tutkimuksissa on havaittu, että vanhemman aktiivinen toiminta nukuttamistilanteessa (esim. lapsen nostaminen syliin) on yhteydessä lapsen uniongelmiin niitä lisäävästi toisin kuin passiivisempi, itsenäisyyteen kannustava nukuttamistyyli $(5,16,26,27,28)$. On ajateltu, että vanhemman liian aktiivisen toiminnan vuoksi lapsi ei opi rauhoittumaan ja nukahtamaan itsenäisesti ilman apua. Liiallinen passiivisuuskaan, kuten lapsen jättäminen itkemään yksin pitkäksi aikaa, ei kuitenkaan ole hyväksi, vaan vanhemmalta vaaditaan toisaalta aktiivista toimintaa ja toisaalta lapsen itsenäisen selviytymisen tukemista (29). Kausaalisuhde ei kuitenkaan ole täysin selvä, vaan kyse voi olla myös siitä, että vaikeammin rauhoittuvat ja nukahtavat lapset tarvitsevat enemmän vanhempiensa apua (12).

Vanhemman kokema stressi on yksi niistä perheympäristön tekijöistä, joita on tutkittu laajasti ja jonka yhteydet uniongelmaan on todettu yksimielisesti (esim. 30-36). Yhteys on ilmeinen arkielämästäkin: lapsen univaikeudet aiheuttavat stressiä koko perheelle. On myös viitteitä toisensuuntaisista vaikutuksista (esim. 37). Stres- 
saantunut vanhempi voi olla vähemmän sensitiivinen vuorovaikutuksessa lapsensa kanssa, joka voi johtaa lapsen uniongelmiin. On myös havaittu, että stressaantuneet äidit kokevat lapsen normaalit yöheräilyt ongelmallisempina kuin ei-stressaantuneet äidit (31).

Tämän tutkimuksen tarkoituksena on analysoida, miten perheympäristö ja lapsen univaikeudet yhteydessä toisiinsa suomalaisessa aineistossa. Tutkimuksessa pyritään selvittämään, kuinka äidin vanhemmuustyylit, äidin vanhemmuuden stressi, vanhempien nukuttamistyylit ja äidin koulutus ja ikä vaikuttavat lapsen univaikeuksiin. Tutkimuksen tavoitteena on tuottaa tietoa, jota voidaan hyödyntää lapsen univaikeuksien tunnistamisessa sekä lapsiperheiden tukemisessa sosiaali- ja terveydenhuollossa.

\section{AINEISTO JA MENETELMÄT}

\section{AINEISTO}

Tämä tutkimus on osa Lapsen uni ja terveys -tutkimushanketta, jossa tutkitaan lapsen unen ja unirytmin varhaista kehittymistä ja unen merkitystä lapsen hyvinvoinnille ja terveydelle. Hankkeen tutkimusaineistona on Pirkanmaan sairaanhoitopiirin alueella huhtikuussa 2011-maaliskuussa 2013 syntynyt ikäkohortti. Hankkeen aineisto kerättiin kyselylomakkeiden avulla neljässä aikapisteessä vuosina 2010-2015. Vanhemmat rekrytoitiin mukaan tutkimukseen neuvolan rutiinitarkastuksen yhteydessä 32. raskausviikolla, jolloin sekä äidille että isälle annettiin omat lomakkeet mukaan kotiin täytettäväksi. Vastaajat palauttivat lomakkeet postitse. Seuraavat äidin, isän ja lapsen lomakkeet postitettiin lapsen ollessa kolmen, kahdeksan ja 24 kuukauden ikäinen.

Tässä tutkimuksessa käytetään äidin ja lapsen aineistoja, jotka on kerätty ennen lapsen syntymää ja lapsen ollessa kahdeksan kuukauden ikäinen. Ennen lapsen syntymää toteutettuun kyselyyn vastasi 1667 äitiä (38). Kahdeksan kuukauden kyselyssä palautettiin yhteensä 1294 lapsen lomaketta ja 1289 äidin lomaketta. Äitien ja lasten vastaukset yhdistettiin, ja tämän tutkimuksen analyyseihin otettiin mukaan ne äiti-lapsiparit, jotka olivat vastanneet kaikkiin kolmeen kyselyyn. Näin otoskooksi saatiin 1291 äiti-lapsiparia.

\section{MUUTTUJAT}

Lapsen univaikeudet kahdella tavalla mitattuna. Selitettävinä muuttujina olivat lapsen univaikeudet kahdella tavalla mitattuna. Lapsen unta mitattiin Infant Sleep Questionnairen (ISQ) (6) avulla, joka on tarkoitettu erityisesti 12-18 kuukauden ikäisten lasten unen laadun arviointivälineeksi. ISQ mahdollistaa unen arvioinnin kolmella vaihtoehtoisella kriteerillä, joista käytimme kahta: summamuuttujaa (severity score eli vakavuuspisteet) sekä vanhemman näkemystä siitä onko lapsella uniongelmaa (maternal criteria). Summamuuttuja muodostettiin mittarin kuudesta muuttujasta, jotka olivat asteikoiltaan 6-8-portaisia. Niiden avulla selvitettiin lapsen nukuttamiseen kuluvaa aikaa (alle 10 minuuttia - tunti tai enemmän), nukahtamisvaikeuksien useutta viikon aikana (harvemmin kuin kerran viikossa - joka ilta), lapsen yöheräilyjen useutta (harvemmin kuin kerran viikossa - joka ilta), lapsen yöheräilyn useutta niin että tarvitsee vanhemman rauhoittelua (ei herää lainkaan - viisi tai useamman kerran yössä)( , uudelleen nukahtamiseen kuluvaa aikaa (alle 10 min. - tunti tai enemmän) sekä sitä, kuinka usein vanhemmat ottavat lapsen viereensä nukkumaan, koska lapsi ei rauhoitu muilla tavoin (harvemmin kuin kerran viikossa - joka yö). Suuremmat arvot tarkoittavat vaikeampaa uniongelmaa. Analyyseissä käytettiin keskiarvosummamuuttujaa puuttuvien tietojen vaikutusten minimoimiseksi.

Toinen unta ja uniongelmaa kuvaava muuttuja, vanhemman näkemys uniongelman olemassaolosta, muodostettiin ISQ-mittarin yhdestä muuttujasta. Vanhemmalta kysyttiin onko hänen mielestään lapsella uniongelmaa, johon vastattiin neljäportaisella asteikolla: ei uniongelmaa, lieviä uniongelmia, kohtalaisia uniongelmia ja vaikeita uniongelmia. Tästä muodostettiin logistista regressioanalyysia varten dikotominen muuttuja niin, että vaihtoehdot lieviä, kohtalaisia ja vaikeita uniongelmia yhdistettiin yhdeksi luokaksi (1=on uniongelma) ja vastausvaihtoehdosta " ei uniongelmaa" tehtiin toinen luokka $(0)$.

Vanhemmunstyyli. Äidin vanhemmuustyyli määriteltiin Parenting styles and dimensions questionnaire -mittarin (PSDQ) (39) avulla. PSDQ erottelee vanhemmuustyylit kolmeen dimensioon: sallivaan, autoritaariseen ja auktoritatiiviseen vanhemmuustyyliin. Luokittelu perustuu Baumrindin (40) teoriaan kasvatustyyleistä. 
Salliva vanhemmuustyyli tarkoittaa, että vanhempi antaa lapsen pitkälti itse säädellä omaa käyttäytymistään, välttää kontrollointia ja yrittää olla rankaisematta lasta vaikka tämä käyttäytyy huonosti. Salliva vanhempi ei välttämättä vaadi lapselta sopivaa käytöstä, ja hän saattaa olla epävarma siitä, kuinka huonoon käytökseen tulisi puuttua. Autoritaarinen vanhempi kontrolloi lasta, ja on valmis käyttämään voimakkaitakin rankaisukeinoja. Autoritaariseen vanhemmuuteen ei kuulu lapsen kanssa keskustelu tai lapsen tahdon arvostaminen, mikäli se on ristiriidassa vanhemman tahdon kanssa. Auktoritatiivinen eli ohjaava vanhempi taas rohkaisee lasta keskustelemaan, perustelee lapselle omat menettelytapansa, arvostaa lapsen omaa tahtoa, mutta myös tottelevaisuutta. $(14,40$.)

Alkuperäisen mittarin 62 väittämästä otettiin mukaan 38. Pois jätettiin sellaiset väittämät, joiden ei ajateltu soveltuvan kyseiseen kontekstiin esimerkiksi siksi, että ne koskivat tilanteita, joissa lapsi on selkeästi vanhempi kuin tutkimuksessa mukana olevat lapset. Mittarin väittämät koskivat erilaisia kasvatuskäytäntöjä ja -tilanteita sekä ajatuksia ja asenteita vanhempana toimimisesta (41). Vanhempia pyydettiin arvioimaan viisiportaisen asteikon (ei koskaan - aina) avulla kuinka usein he toimivat väittämän kaltaisesti. Väittämistä 12 kuvasi auktoritatiivista vanhemmuutta, 12 autoritaarista vanhemmuutta ja 14 sallivaa vanhemmuutta. Näistä muodostettiin kolme keskiarvosummamuuttujaa, yksi jokaista vanhemmuustyyliä kuvaamaan.

Vanhemmuuden stressi. Äidin vanhemmuuden stressiä mitattiin Parenting Stress Inventory -mittarilla (PSI) (42). Mittari sisälsi 23 väittämää, joihin vastaajia pyydettiin vastaamaan sopivalla vastausvaihtoehdolla sen mukaan, olivatko he kohdanneet kysyttyjä ongelmia viimeisen kahden viikon aikana ja kuinka vaikeita ne olivat olleet. Ongelmat liittyivät vauvaperheen arkeen, esimerkiksi oma unenpuute, muutokset parisuhteessa ja vauvan rauhattomuus. Niihin vastattiin neljäportaisella asteikolla; "en ole kokenut", "olen kokenut, ei vaikeita", olen kokenut, jokseenkin vaikeita" ja "olen kokenut, hyvin vaikeita”. Väittämistä muodostettiin keskiarvosummamuuttuja.

Nukuttamistyyli (rauboittelutyyli). Vanhemman nukuttamistyyliä selvitettiin Parental Interactive Bedtime Behaviour Scale -mittarin avulla
(PIBBS) (26). Nukuttamistyylejä ei selvitetty molemmalta vanhemmalta erikseen, vaan kysymys oli lapsen lomakkeessa. Pääsääntöisesti kyseessä on äidin käyttämä nukuttamistyyli, koska lapsen lomakkeen täyttäjänä oli 70-prosenttisesti äiti ja lähes kaikissa muissa vanhemmat yhdessä Kysymys sisälsi 21 erilaista rauhoittelu- ja nukuttamistapaa, joihin jokaiseen vastattiin viisiportaisella asteikolla (ei koskaan-hyvin usein) sen mukaan, kuinka usein kyseistä tapaa käyttää. Näistä muodostettiin mittarin ohjeen mukaisesti viisi keskiarvosummamuuttujaa, jotka kuvaavat seuraavia tyylejä: aktiivinen fyysinen rauhoittelutyyli (kuusi muuttujaa, esim. vauvan sylissä pitäminen, kanniskelu ja silittely), itsenäisyyteen kannustava rauhoittelutyyli (kolme muuttujaa: musiikin kuuntelu, lelun tai unirätin antaminen ja lapsen jättäminen itkemään), liikkeen avulla rauhoitteleminen (kaksi muuttujaa: vaunuja työnnellen tai autoajelulla), passiivinen fyysinen rauhoittelutyyli (lapsen sängyn vieressä seisominen tai lapsen vieressä makaaminen) ja sosiaalinen rauhoittelutyyli (neljä muuttujaa, esim. tuutulaulun laulaminen ja sadun lukeminen).

Äidin koulutus. Äideiltä kysyttiin ennen lapsen syntymää täytetyssä lomakkeessa ammatillista koulutusta (ei ammatillista koulutusta, ammatillinen kurssi/kursseja, ammattikoulu, opisto tai ammattikorkeakoulu, yliopisto tai korkeakoulu). Muuttujasta tehtiin kolmeluokkainen: yliopisto tai korkeakoulu, opisto tai ammattikorkeakoulu ja alempi kuin opisto. Lisäksi i analyyseissä selittävänä muuttujana oli äidin ikä lapsen syntyessä, joka muodostettiin äidin syntymäajasta.

\section{TILASTOLLISET MENETELMÄT}

Lapsen uniongelman ja perheympäristön välistä yhteyttä tarkasteltiin kahden eri analyysimenetelmän, logistisen ja lineaarisen regressioanalyysin avulla. Molemmissa käytettiin samoja selittäjiä, mutta selitettävä muuttuja oli eri. Logistisessa regressioanalyysissa selitettävänä muuttujana oli dikotominen muuttuja vanhemman näkemyksestä uniongelman olemassaolosta (ei uniongelmaa - on uniongelma). Toiseksi analyysimenetelmäksi valittiin lineaarinen regressio, koska siinä selitettävänä muuttujana oli jatkuva muuttuja, eli lapsen uniongelma summamuuttujalla kuvattuna. Molemmat regressioanalyysit toteutettiin vaiheittain selittäviä muuttujia lisäämällä niin, että malleja muodostui molemmissa analyyseissa kuusi 
Taulukko 1. Analyyseissa käytettyjen muuttujien kuvailevat tunnusluvut.

\begin{tabular}{|c|c|c|c|c|c|}
\hline & Keskiarvo/\% & Keskihajonta & Vaihteluväli & $\mathbf{N}$ & $\begin{array}{l}\text { Cronbachin } \\
\text { alfa }\end{array}$ \\
\hline Äidin ikä & 30,73 & 4,48 & $19-48$ & 1277 & - \\
\hline \multicolumn{6}{|l|}{ Äidin ammatillinen koulutus } \\
\hline $\begin{array}{l}\text { Alempi kuin opisto tai } \\
\text { ammattikorkeakoulu }\end{array}$ & 28 & & & & \\
\hline Opisto tai ammattikorkeakoulu & 37 & & & & \\
\hline Yliopisto tai korkeakoulu & 35 & & & & \\
\hline $\begin{array}{l}\text { Lapsen uniongelma dikotomisella } \\
\text { muuttujalla mitattuna }\end{array}$ & ,40 & ,49 & $0-1$ & 1283 & - \\
\hline Ei uniongelmaa & 60 & & & & \\
\hline On uniongelma & 40 & & & & \\
\hline $\begin{array}{l}\text { Lapsen uniongelma summamuuttujalla } \\
\text { mitattuna }\end{array}$ & 2,18 & 1,05 & ,17-7 & 1290 & ,57 \\
\hline Auktoritatiivinen vanhemmuustyyli & 4,21 &, 34 & $2,08-5$ & 1285 & ,76 \\
\hline Autoritäärinen vanhemmuustyyli & 1,65 & ,36 & $1-3,17$ & 1284 & ,73 \\
\hline Salliva vanhemmuustyyli & 1,90 &, 30 & $1-3,07$ & 1284 &, 53 \\
\hline Aktiivinen fyysinen nukuttamistyyli & 2,75 &, 76 & $1-5$ & 1290 &, 58 \\
\hline $\begin{array}{l}\text { Itsenäisyyteen kannustava } \\
\text { nukuttamistyyli }\end{array}$ & 2,25 &, 78 & $1-5$ & 1283 &, 18 \\
\hline Liikkeen avulla nukuttaminen & 2,36 & ,93 & $1-5$ & 1287 & ,38 \\
\hline Passiivinen fyysinen nukuttamistyyli & 2,35 & 1,10 & $1-5$ & 1285 &, 59 \\
\hline Sosiaalinen nukuttamistyyli & 1,98 &, 74 & $1-5$ & 1284 & ,50 \\
\hline Äidin stressi & 1,71 &, 35 & $1-3,52$ & 1284 &, 87 \\
\hline
\end{tabular}

erilaista. Regressiomalleissa mukana olevien summamuuttujien reliabiliteettien varmistamiseksi käytettiin Cronbachin alfakertoimia (Taulukko 1). Aineisto analysoitiin SPSS for Windows 21.0 -tilasto-ohjelmalla. Tilastollisen merkitsevyyden rajana pidettiin $\mathrm{p}$-arvoa $<0,05$ vakiintuneen tulkinnan mukaisesti.

\section{TULOKSET}

Taulukossa 1 on esitetty analyyseissa käytettyjen muuttujien kuvailevia tietoja.. Tutkimuksessa mukana olevien äitien keski-ikä oli noin 31 vuotta. 45 prosenttia heistä oli 30-35-vuotiaita ja 34 prosenttia 25-29-vuotiaita. Alle 25-vuotiaita oli vain seitsemän ja yli 25 -vuotiaita neljätoista prosenttia. 40 prosenttia vastanneista koki lapsellaan olevan jonkin asteisia uniongelmia, pääasiassa lieviä (30\%). Yhdeksän prosenttia koki lapsellaan olevan kohtalaisia ja prosenttia lieviä uniongelmia.

Ensin tarkastelimme perheympäristön yhteyttä lapsen uniongelmaan logistisen regressioanalyysin avulla. Selitettävänä muuttujana oli vanhemman mielipide siitä, onko lapsella union- gelmaa. Jotta saatiin selvitettyä, missä vaiheessa selittäjien efektit mahdollisesti katoavat, selittäjät lisättiin malliin vaiheittain. Ensimmäinen malli (Malli 2.1) koostui yhden selittäjän malleista, joissa mitään muuttujia ei ole vakioitu. Tämän jälkeen lähdimme liikkeelle kiinnostavimmista muuttujista eli äidin vanhemmuustyyleistä (Malli 2.2). Seuraavaan malliin (Malli 2.3) lisättiin mukaan nukuttamistyyli ja neljänteen (Malli 2.4) äidin vanhemmuuden stressi. Malliin 2.5 malliin lisättiin äidin koulutus ja viimeiseen malliin (Malli 2.6) äidin ikä. Taulukossa 2 on esitetty logistisen regressioanalyysin tulokset.

Yhden selittäjän malleissa vanhempien kokemukseen lapsen uniongelman olemassaolosta oli yhteydessä sitä lisäävästi salliva vanhemmuustyyli, nukuttamistyylit itsenäisyyteen kannustavaa lukuun ottamatta, äidin stressi ja äidin korkein koulutus. Kuitenkin sallivan vanhemmuustyylin ja sosiaalisen nukuttamistyylin efektit hävisivät heti kolmannessa mallissa, jossa selittäjiksi lisättiin vanhemmuustyylien lisäksi nukuttamistyylit. Vaiheittaiset logistiset regressioanalyysit tuottivat lapsen uniongelman parhaiksi selittäjiksi 


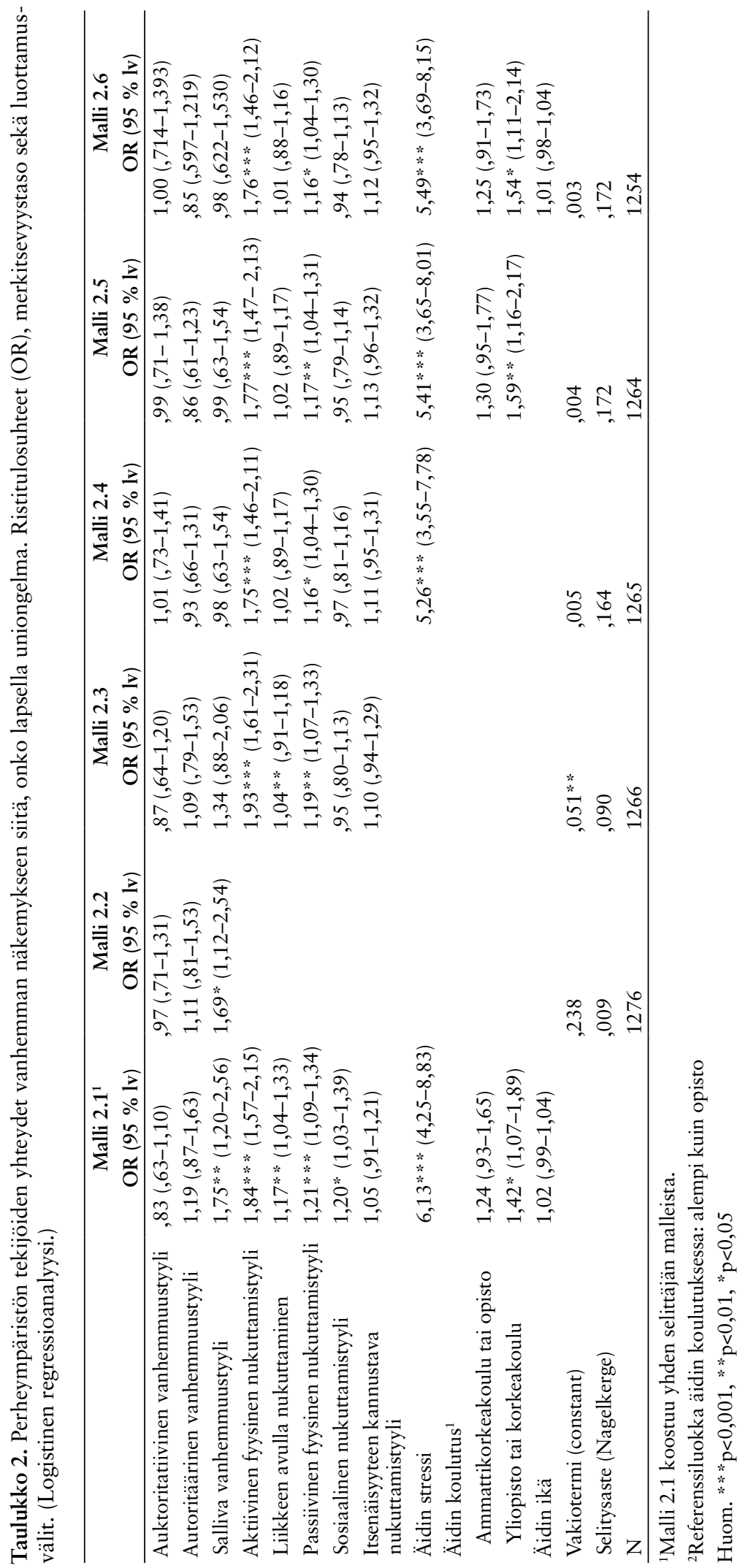




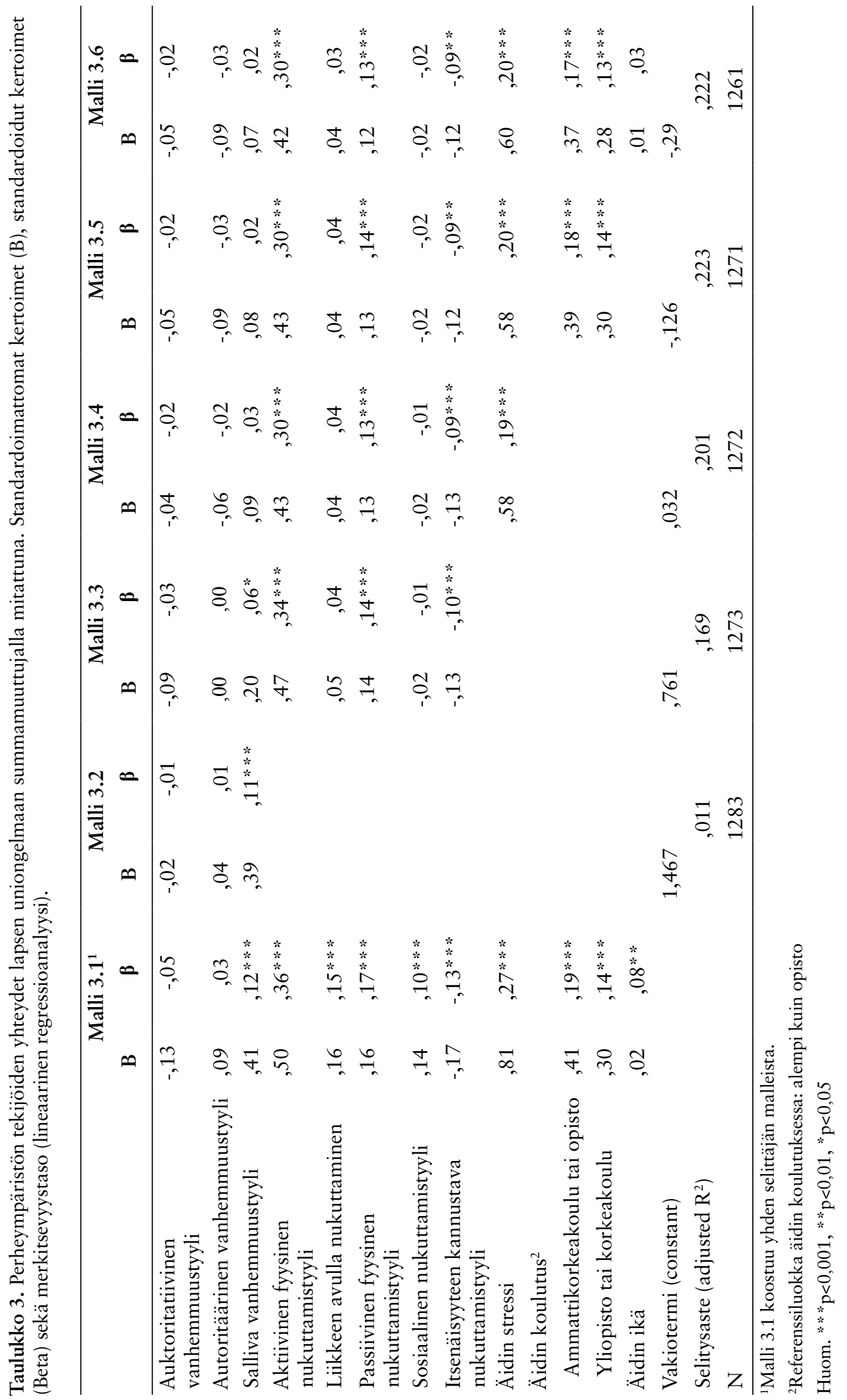


näennäisselitysasteen perusteella Mallit 3.5 ja 3.6, joissa selittäjinä ovat äidin vanhemmuustyylit, vanhemmuuden stressi ja koulutus sekä vanhemman nukuttamistyylit ja Mallissa 3.6 lisäksi äidin ikä. Näennäisselitysasteen perusteella mallit kykenivät selittämään 17,2 prosenttia selitettävän muuttujan vaihtelusta. Logistisen regressioanalyysin perusteella vanhemman riskiin arvioida lapsella olevan uniongelma oli voimakkaimmin yhteydessä vanhemmuuden stressi. Mitä enemmän vanhemmuuden stressiä äidillä oli, sitä suurempi oli riski sille, että lapsella oli arvioitu olevan uniongelma. Myös äidin koulutustason noustessa nousi riski arvioida lapsella olevan uniongelma. Molempien fyysisten nukuttamistyylien käyttö lisäsi myös tätä riskiä. Lapsen uniongelman ja perheympäristön välistä yhteyttä tarkasteltiin seuraavaksi lineaarisen regressioanalyysin avulla. Selitettävänä muuttujana oli uniongelmaa kuvaava summamuuttuja ja selittäjinä samat muuttujat kuin logistisessa regressioanalyysissä. Analyysit tehtiin samalla tavalla kuin logistisessa regressioanalyysissa lisäten muuttujia vaiheittain mukaan. Tulokset on esitetty Taulukossa 3.

Lineaarisen regressioanalyysin tulokset ovat hyvin samansuuntaisia logistisen regressioanalyysin kanssa. Ensimmäisessä mallissa (Malli 3.1) muuttujia ei ole vakioitu. Sen standardoitujen kertoimien perusteella lapsen uniongelmaan sitä lisäävästi ovat yhteydessä kaikki nukuttamistyylit, salliva vanhemmuustyyli, äidin stressi ja korkea koulutus. Seuraavassa mallissa, jossa selittävinä muuttujina olivat vanhemmuustyylit, salliva vanhemmuustyyli oli edelleen yhteydessä lapsen uniongelmaan. Kun malliin lisättiin nukuttamistyylit, sosiaalisen nukuttamistyylin ja liikkeen avulla nukuttamisen efektit katosivat verrattuna ensimmäiseen malliin. Seuraavassa mallissa, johon lisättiin äidin vanhemmuuden stressi, hävisi sallivan vanhemmuustyylin efekti (Malli 3.3). Mallien selitysasteiden perusteella parhaiten uniongelmaa selitti Malli 3.5, jossa mukana on edellisten lisäksi äidin koulutus. Mallin selitysaste on 22,3\%. Malli, jossa kaikki selittäjät olivat mukana, oli selitysasteeltaan lähes yhtä hyvä (22,2\%) (Malli 3.5).

Standardoitujen kertoimien perusteella vanhempien aktiivinen fyysinen nukuttamistyyli oli vahvimmin yhteydessä lapsen univaikeuteen. Mitä enemmän vanhempi käytti aktiivista fyy- sistä nukuttamistyyliä, sitä enemmän lapsella oli univaikeuksia. Myös vanhempien passiiviset fyysiset nukuttamiskeinot vaikuttivat lapsen uniongelmaan sitä lisäävästi. Sen sijaan itsenäisyyteen kannustava nukuttamistyyli oli yhteydessä vähäisempiin uniongelmiin. Lisäksi i lapsen korkeammin kouluttautuneilla ja korkeampaa stressiä kokevien äitien lapsilla oli enemmän uniongelmia.

\section{POHDINTA}

Tässä artikkelissa tutkittiin perheympäristön merkitystä lapsen unen kannalta. Tutkimuksen tuloksena oli, että äidin vanhemmuuden stressi ja vanhemman aktiivisten sekä passiivisten fyysisten nukuttamistyylien käyttö ja äidin korkea koulutus olivat yhteydessä lapsen uniongelmiin. Samantyyppinen yhteys liittyi sekä vanhemman käsitykseen lapsen uniongelmasta että uniongelman vaikeusasteeseen summamuuttujalla mitattuna. Lisäksi itsenäisyyteen kannustavan nukuttamistyylin havaittiin olevan yhteydessä summamuuttujan avulla arvioituun uniongelmaan sitä vähentävästi. Vaiheittaiset regressioanalyysit osoittivat, että myös äidin salliva nukuttamistyyli oli yhteydessä lapsen uniongelmiin. Myös aikaisemmissa vanhemmuustyyliä koskevissa tutkimuksissa (22, 23 sit. 24) on havaittu sallivan ja rennon vanhemmuustyylin olevan yhteydessä lisääntyneisiin uniongelmiin. Kuitenkin tutkimuksessamme tämä yhteys hävisi, kun lineaariseen regressiomalliin lisättiin äidin kokema vanhemmuuden stressi ja logistiseen regressiomalliin lisättiin nukuttamistyylit. Jatkossa olisikin syytä tutkia vanhemmuustyylin epäsuoria vaikutuksia uniongelmaan eri mediaattorimuuttujien kautta.

On havaittu, että vanhemmuustyyli voi vaikuttaa lapsen uneen sen kautta, kuinka vanhempi toimii nukuttamistilanteessa. Tutkimusaineistossamme vahvin, vaikkakin heikko korrelaatio vanhemmuustyylien ja nukuttamistyylien välillä oli sallivan vanhemmuustyylin ja aktiivisen fyysisen nukuttamistyylin välillä. Aikaisemmin on havaittu, että auktoritatiiviset vanhemmat ovat vähemmän aktiivisia nukuttamistilanteessa, joka taas on yhteydessä lapsen ongelmattomaan nukkumiseen (25). Tutkimuksemme ei vahvistanut suoraan tätä tulosta. Yleisesti ottaen pienten lasten vanhempien vanhemmuustyylien yhteyttä lapsen nukkumiseen on tutkittu hyvin vähän, eikä tiedossamme ole yhtään tutkimusta, jossa 
olisi tarkasteltu unen ja Baumrindin typologiaan perustuvan vanhemmuustyylin yhteyttä. Aihe vaatii lisää tutkimusta, sillä tutkimuksemme antoi vain viitteitä mahdollisesta yhteydestä.

Tutkimuksessamme fyysiset nukuttamistyylit, olivat yhteydessä lapsen uneen. Tulos aktiivisen fyysisen nukuttamistyylin yhteydestä lapsen uneen on linjassa aikaisempien tutkimusten kanssa $(26,5,27,16)$. Itsenäisyyteen kannustavan nukuttamistyylin ja lapsen uniongelman välillä oli negatiivinen yhteys lineaaristen regressiomallien perusteella, mutta logistiset mallit eivät osoittaneet tätä yhteyttä. Itsenäisyyteen kannustavan nukuttamistyylin ja uniongelman väliseen yhteyteen on suhtauduttava varauksella, sillä sitä kuvaavan summamuuttujan alhainen Cronbachin alfakerroin kertoo summamuuttujan huonosta reliabiliteetista. Vaikka regressioanalyysin oletuksiin kuuluu, että tekijöiden välillä on yksisuuntainen suora yhteys (43), tässä tutkimuksessa ei voida tehdä varmoja tulkintoja vaikutussuhteiden suunnista lapsen unen ja perheympäristöön liittyvien tekijöiden välillä. Useimmat tutkimukset ovat jättäneet kausaalitulkinnat tekemättä, ja tarvitaankin lisää tutkimusta vaikutussuhteiden selvittämiseksi. Bronfenbrennerin (13) lapsen kehitystä selittävän bioekologisen teorian lähtöoletuksena on, lapsi ja hänen ympäristönsä ovat jatkuvassa vuorovaikutuksessa keskenään, eivätkä vaikutukset ole koskaan yhdensuuntaisia. Erityisesti vanhemmuuden stressin ja unen välinen yhteys voi olla mutkikas: vauvan uniongelmat lisäävät luonnollisesti vanhemman kokemaa stressiä, mutta myös vanhemman stressi voi vaikuttaa lapsen uneen sitä heikentävästi. Stressaantunut vanhempi voi olla vähemmän sensitiivinen ollessaan vuorovaikutuksessa lapsen kanssa, mikä vaikuttaa lapsen hyvinvointiin ja turvallisuuden kokemukseen. Tämä taas voi ilmetä nukkumisvaikeuksina. Stressi oli analyyseissa mukana olevista tekijöistä kaikista voimakkaimmin yhteydessä lapsen uniongelmaan ja vanhempien kokemukseen uniongelman olemassaolosta. On myös havaittu, että stressaantuneet vanhemmat kokevat lapsen unen ongelmallisemmaksi kuin se todellisuudessa onkaan $(32,44)$. Subjektiivisilla unimittareilla onkin vaikea osoittaa, millaisesta yhteydestä on kyse.

Samoin vanhemman käyttämän nukuttamistyylin ja lapsen unen välinen yhteys voi olla kahdensuuntainen (10). Vanhemman nukuttamistilanteessa omaksuman aktiivisen roolin on ajateltu vaikuttavan lapsen kykyyn oppia omia hallintakeinoja ja autonomian kehittämiseen (10). Todellisuudessa vanhemman käyttämät nukuttamistyylit voivat muuttua sen mukaan kuinka lapsi niihin reagoi. Lapsi, jolla on vaikeuksia rauhoittua, vaatii vanhemmalta enemmän apua ja läsnäoloa (10). Kun tulokset stressin ja unen sekä nukuttamistyylin ja unen välisistä yhteyksistä olivat jotakuinkin linjassa aikaisempien tutkimusten kanssa, niin tulokset äidin koulutuksen vaikutuksesta lapsen uneen olivat ristiriidassa aikaisempiin löydöksiin verrattuna. Useat tutkimukset ovat osoittaneet, että korkeammin koulutettujen äitien (tai vanhempien) lapset nukkuvat paremmin $(35,45)$. Tutkimuksessamme sen sijaan yhteys oli päinvastainen: Korkeimmin koulutettujen äitien lapsilla oli enemmän uniongelmia. Tutkimuksemme jättää avoimeksi kysymyksen siitä, mikä sai aikaan tuon yhteyden. Aikaisemmatkaan tutkimukset eivät ole päässeet selvyyteen, millaisten lähiprosessien ja mekanismien kautta äidin koulutus ulottuu lapsen uneen.

Tällä tutkimuksella on rajoituksia, jotka on otettava huomioon arvioitaessa tulosten luotettavuutta. Ensimmäinen niistä liittyy uniongelman mittaamiseen subjektiivisilla menetelmillä. Tutkimuksessamme uniongelman määrittely perustui vanhemman raportointiin kahdella eri tavalla. Vanhempi sai itse määritellä, onko hänen mielestään lapsella uniongelmia. Toiseksi uneen liittyvistä monivalintakysymyksistä muodostettiin summamuuttuja, jonka suuremmat arvot tarkoittivat vakavampia uniongelmia. Vaikka molemmat tavat perustuivat validoituun mittariin, piilee subjektiivissa mittareissa aina riski tulosten epäluotettavuudesta. Luotettavuuden parantamiseksi päädyimmekin ottamaan tutkimukseen mukaan nämä kaksi erilaista uniongelmamuuttujaa. Lasten ja nuorten unen tutkimuksissa useiden menetelmien käyttö on suositeltavaa (46).

Usein pienen lapsen uni koetaan ongelmalliseksi silloin, kun se häiritsee vanhemman unta. Tällöin kyseessä on lapsen ja vanhemman välinen goodness-of-fit, eli mitä yhteensopivammat unirytmit lapsella ja vanhemmalla on, sitä epätodennäköisemmin lapsen unessa koetaan olevan ongelmia. Näinpä kahdesta samalla tavalla nukkuvasta lapsesta vain toisen kohdalla puhutaan 
uniongelmasta, koska lapsen vanhemmat kokevat unen olevan ongelmallista (10). On myös havaittu, että masentuneet, stressaantuneet ja negatiivisesti lapseensa suhtautuvat äidit kokevat lapsen unen ongelmallisempana kuin se todellisuudessa onkaan $(32,44)$. Täten äidin oma määrittely siitä, onko lapsella uniongelma vai ei, ei ole täysin luotettava. Kuitenkin myös uniongelmaa kuvaavan summamuuttujan perusteella uniongelmasta kärsi suurin piirtein yhtä suuri osuus vastanneiden lapsista. Tämäkään ei riitä todistamaan mittarin luotettavuutta, sillä aikaisemmat tutkimukset ovat osoittaneet, että stressaantuneet vanhemmat myös arvioivat lapsen yöheräilyjen määrän todellisuutta korkeammaksi. Tässä tutkimuksessa löydettyjen yhteyksien, erityisesti unen ja vanhemman stressin, todellisesta luonteesta olisi mahdollista saada parempi käsitys objektiivisten unimittareiden tuottaman tiedon avulla.

Vanhemmuustyylin kuvaamiseen käytettiin mittaria, joka on kehitetty ja validoitu Amerikassa. Mittarin soveltaminen eri kulttuurioloihin ei ole ongelmatonta. Mittari ei myöskään kaikilta osin sopinut näin pienten lasten vanhempien vanhemmuustyylin mittaamiseen eikä mitannut sen hetkistä käyttäytymistä, vaan vastaajia pyydettiin arvioimaan, kuinka he toimisivat tilanteissa, joissa lapsi on jo hieman vanhempi. Tiedossamme ei ole, ette mittaria olisi käytetty aikaisemmin tutkittaessa näin pienten lasten äitien vanhemmuustyylejä. Tarvitaan siis lisätutkimusta ja mahdollisesti myös muiden vanhemmuustyylimittareiden hyödyntämistä.

Vaikka tutkimuksessa havaittiin yhteys tiettyjen nukuttamistyylien ja uniongelman välillä, ei sen perusteella voi päätyä yksinkertaistettuihin neuvoihin siitä, kuinka lapsi tulisi nukuttaa. Lapset ovat yksilöitä ja hyötyvät todennäköisesti kukin hieman erilaisista lähestymistavoista. Erityisesti itsenäisyyteen kannustavan nukuttamistyylin ja lapsen uniongelman väliseen yhteyteen on suhtauduttava varauksella itsenäisyyteen kannustavan nukuttamistyylin summamuuttujan reliabiliteetin alhaisuuden vuoksi.
Tutkimuksemme vahvuutena on laaja kohorttiaineisto, jollaista ei ole aikaisemmin kerätty Suomessa kyseisestä tutkimusaihepiiristä. Kyseessä on pitkittäistutkimus, jossa lapsia seurataan useiden vuosien ajan. Pitkittäisasetelmalla saadaan arvokasta tietoa uniongelmien kehittymisestä. Tutkimushanke, joka on vastannut tässä tutkimuksessa käytetyn aineiston keräämisestä, on tehnyt merkittävää pioneerityötä yhdistämällä useita eri tieteenaloja lapsen unen ja siihen vaikuttavien tekijöiden tutkimiseksi. Hankkeessa yhdistyy geenitutkimus, psykologia, sosiaalitieteet ja pediatria. Näiden alojen yhteystyönä saadaan muodostettua aikaisempaa kattavampi kuva lasten uniongelmien synnystä ja kehityksestä. Tutkimuksemme tuloksia voidaan toivottavasti käyttää tukena muun tutkimustiedon ohella lapsen univaikeuksien tunnistamisessa sekä lapsiperheiden tukemisessa sosiaali- ja terveydenhuollossa. Ennaltaehkäisevä työ, riskitekijöiden tunnistaminen ja niihin puuttuminen varhaisessa vaiheessa myös lapsen uniongelmien kohdalla voi ehkäistä jopa lastensuojeluasiakkuuksien syntymistä.

\section{KIRJOITTAJIEN KONTRIBUUTIOT}

Häkälä oli vastuussa käsikirjoituksen kirjoittamisesta, tilastollisten analyysien tekemisestä ja tulkinnasta sekä osallistui artikkelin pohjana olevan aineiston hankintaan. Pölkki on Perheympäristö ja lapsen uni-osahankkeen vastuuhenkilö sekä Häkälän väitöskirjatyön ohjaaja. Pölkki osallistui artikkelin analysointiin ja kirjoittamiseen. Hämäläinen on Häkälän väitöskirjatyön ohjaaja. Hämäläinen osallistui artikkelin analysointiin ja kirjoittamiseen. Paunio on koko projektin suunnittelija ja geneettisen tutkimuksen vastuuhenkilö Child-Sleep-projektissa. Kylliäinen osallistui kohortin tutkimussuunnitelman suunnitteluun ja toimi psykologisten osuuksien vastuuhenkilönä. Saarenpää-Heikkilä toimi artikkelin pohjana olevan aineiston hankinnan vastuuhenkilönä ja osallistui artikkelin analysointiin. Paavonen osallistui tutkimusprojektin suunnitteluun ja organisointiin, artikkelin analysointiin ja kirjoittamiseen. 
This study focused on the connection between factors of family environment, such as mother's parental stress, mother's parenting style, and soothing method and children's sleep problems at the age of eight months. This study used survey data from the Child Sleep Study. The longitudinal data is collected from parents of children born in 2011 and 2012. The Child Sleep Study is being executed in the Pirkanmaa hospital district. In this study we used the data which was collected before birth $(\mathrm{n}=1667)$ and when children turned eight months (mothers' $\mathrm{n}=1289$ and children's
$\mathrm{n}=1294)$.Logistic and linear regression analyses were used as analyzing methods. Findings indicated that child's sleep problems were connected to maternal stress, mother's higher education, and passive physical soothing methods used.

Keywords: infant sleep, parenting style, soothing method, parental stress

Saapunut 13.3.2017

Hyväksytty 22.6.2017

\section{LÄHTEET}

(1) Paavonen EJ, Aronen ET, Moilanen I, ym. Sleep problems of school-aged children: a complementary view. Acta Paediatr 2000;89:223-228.

https://doi.org/10.1111/j.1651-2227.2000. tb01220.x

(2) Kronholm E, Puusniekka R, Jokela J, ym. Trends in self-reported sleep problems, tiredness and related school performance among Finnish adolescents from 1984 to 2011. J Sleep Res 2015:24:3-10.

https://doi.org/10.1111/jsr.12258

(3) Mindell JA, Owens, JA. A clinical guide to pediatric sleep. Diagnosis and management of sleep problems. Second edition. Philadelphia USA: Lippincott Williams \& Wilkins; 2010.

(4) El-Sheikh M. Introduction and Overview. Salient Issues in the Consideration of Sleep in Context. Kirjassa: El-Sheikh M. (toim.) Sleep and Development. Familial and Socio-Cultural Considerations. New York USA: Oxford University Press; 2011, xi-xv. https://doi.org/10.1093/ acprof:oso/9780195395754.001.0001

(5) Sadeh A, Tikotzky L, Scher A. Parenting and infant sleep. Clinical review. Sleep Med Rev 2010;14:89-96. https://doi.org/10.1016/j.smrv.2009.05.003

(6) Morrell JMB. The infant sleep questionnaire: A new tool to assess infant sleep problems for clinical and research purposes. Child Psychol Psychiatry Review 1999;4:20-26. https://doi.org/10.1017/S1360641798001816

(7) Armitage R, Flynn H, Hoffmann R, ym. Early developmental changes in sleep in infants: The impact of maternal depression. Sleep 2009;32:693-696. https://doi.org/10.1093/sleep/32.5.693

(8) St James-Roberts I. Helping parents to manage infant crying and sleeping: A review of the evidence and its implications for services. Child Abuse Rev 2007;16:47-69. https://doi.org/10.1002/car.968

(9) Saarenpää-Heikkilä O. Koululaisten uniongelmia voidaan ehkäistä ennalta. Suom Lääkäril 2006;64:35-41.

(10) Pajulo M, Pyykkönen N, Karlsson L. Vanhemmuus ja pienten lasten unihäiriöt. Suom Lääkäril 2012;40:2813-2817a.

(11) Jenni O. G., O’Connor B. M. (2005). Children's sleep: An interplay between culture and biology. Pediatr. 2005;115:204-216. https://doi.org/10.1542/peds.2004-0815B

(12) Blunden S. L., Thompson, K. R., Dawson, D. Behavioural sleep treatments and night time crying in infants: Challenging the status quo. Sleep Med Rev 2011;15:327-334. https://doi.org/10.1016/j.smrv.2010.11.002

(13) Bronfenbrenner U, Morris PA. The bioecological model of human development. Kirjassa: Handbook of Child Psychology I:14; 2006, 793-828.

DOI: $10.1002 / 9780470147658 . c h p s y 0114$ https://doi.org/10.1002/9780470147658. chpsy0114

(14) Kivijärvi S, Rönkä A, Hyväluoma J. Vanhemmuus arjessa: Neuvottelua, hässäköitä ja hassuttelua. Kirjassa: Rönkä A, Malinen K, Lämsä T. (toim.) Perhe-elämän paletti. Vanhempana ja puolisona vaihtelevassa arjessa. Jyväskylä: Ps-Kustannus; 2009, 47-68.

(15) Vilhula A. Sosiaalinen perimä. Ylisukupolviset kohtalot tutkimuskirjallisuuden valossa. Helsinki: Suomen Mielenterveysseura; 2007. 
(16) Scher A, Blumberg O. Night waking among 1-year olds: a study of maternal separation anxiety. Child Care Health Dev 1999;25:323334.

https://doi.org/10.1046/j.13652214.1999.00099.x

(17) Raphael-Leff J. Facilitators and regulators: Two approaches to mothering. Br J Med Psychol 1983;56:379-390.

https://doi.org/10.1111/j.2044-8341.1983. tb01571.x

(18) Scher A. Maternal separation anxiety as a regulator of infants' sleep. J Child Psychol Psychiatry 2008;49:618-625.

https://doi.org/10.1111/j.1469-

7610.2007.01872.x

(19) Chou M, Chou W, Chiang H, ym. Sleep problems among Taiwanese children with autism, their siblings and typically developing children. Res Autism Spectr Disord 2012;6:665672.

https://doi.org/10.1016/j.rasd.2011.09.010

(20) Chorpita BF, Barlow DH. The development of anxiety: The role of control in the early environment. Psychol Bull 1998;124:3-21. https://doi.org/10.1037/0033-2909.124.1.3

(21) Philips N, Sioen I, Michels N, ym. The influence of parenting style on health related behavior of children: findings from the ChiBS study. Int J Behav Nutr Phy 2014:11.

(22) Meijer AM, Habekothe RT, Van Den Witenboer GLH. Mental health, parental rules, and sleep in pre-adolescents. J Sleep Res 2001;10:297-302. https://doi.org/10.1046/j.13652869.2001.00265.x

(23) Owens-Stively J, Frank N, Smith A, ym. Child temperament, parenting discipline style, and daytime behavior in childhood sleep disorders. J Dev Behav Pediatr 1997;18:314-21. https://doi.org/10.1097/00004703-19971000000005

(24) Spilsbury JC, Storfer-Isser A, Drotar D, ym. Effects of the home environment on school-aged children's sleep. Sleep 2005;28:1419-1427. https://doi.org/10.1093/sleep/28.11.1419

(25) Johnson N, McMahon C. Preschoolers sleep behaviour: associations with parental hardiness, sleep-related cognitions and bedtime interactions. J Child Psychol Psychiatry 2008;49:765-773.

https://doi.org/10.1111/j.1469.

7610.2007.01871.x

(26) Morrell J, Cortina-Borja M. The developmental change in strategies parents employ to settle young children to sleep, and their relationship to infant sleeping problems, as assessed by a new questionnaire: the parental interactive bedtime behaviour scale. Inf Child Dev 2002;11:17-41. https://doi.org/10.1002/icd.251
(27) Cronin A, Halligan, SL, Murray L. Maternal psychosocial adversity and the longitudinal development of infant sleep. Infancy 2008;13:469-495. https://doi.org/10.1080/15250000802329404

(28) Phillbrook L, Teti D M. Bidirectional associations between bedtime parenting and infant sleep: parenting quality, parenting practices, and their interaction. J. Fam. Psychol 2016; 30; 431-441. https://doi.org/10.1037/fam0000198

(29) Paavonen J, Pölkki P, Vierikko E ym. Uni perhesuhteiden haastajana. Kirjassa: Reivinen J, Vähäkylä L. (toim.) Ketä kiinnostaa? Lasten ja nuorten hyvinvointi ja syrjäytyminen. Helsinki: Gaudeamus; 2013, 137-150.

(30) Melzer LJ, Mindel JA. Relationship between child sleep disturbances and maternal sleep, mood, and parenting stress: a pilot study. J Fam Psychol 2007;21:67-73.

https://doi.org/10.1037/0893-3200.21.1.67

(31) Doo S, Wing YK. Sleep problems of children with pervasive developmental disorders:

Correlation with parental stress. Dev Med Child Neurol 2006;48:650-655. https://doi.org/10.1017/S001216220600137X

(32) Scott G, Richards MPM. Night waking in 1-year-old children in England. Child Care Health Dev 1990;16:283-302.

https://doi.org/10.1111/j.1365-2214.1990. tb00662.x

(33) Ievers-Landis CE, Storfer-Isser A, Rosen C, ym. Relationship of sleep parameters, child psychological functioning, and parenting stress to obesity status among preadolescent children. J Dev Behav Pediatr 2008;29:243-252. https://doi.org/10.1097/ DBP.0b013e31816d923d

(34) Byars KC, Yeomans-Maldonado G, Noll JG. Parental functioning and pediatric sleep disturbance: An examination of factors associated with parenting stress in children clinically referred for evaluation of insomnia. Sleep Med 2011;12:898-905. https://doi.org/10.1016/j.sleep.2011.05.002

(35) Sadeh A, Raviv A, Gruber R. Sleep patterns and sleep disruptions in school-age children. Dev Psychol 2000;36:291-301. https://doi.org/10.1037/0012-1649.36.3.291

(36) Caldwell B, Redeker NS. Maternal stress and psychological status and sleep in minority preschool children. Public Health Nurs 2015; 32:101-111. https://doi.org/10.1111/phn.12104

(37) Bell BG, Belsky J. Parents, parenting, and children's sleep problems: Exploring reciprocal effects. Dev Psychol 2008;26:579-593. https://doi.org/10.1348/026151008X285651 
(38) Paavonen EJ, Saarenpää-Heikkilä O, Pölkki $\mathrm{P}, \mathrm{ym}$. Maternal and paternal sleep during pregnancy in the Child-Sleep birth cohort. Sleep during pregnancy. Painossa.

(39) Robinson CC, Mandleco B, Olsen SF, ym. Parenting Styles and Dimensions Questionnaire (PSDQ). Kirjassa: Perlmutter BF, Touliatos J, Holden GW. Handbook of Family Measurement Techniques. Instruments \& Index Vol 3. California USA: Sage Publications; 2001, 319-321. (Alkuperäinen lähde: Robinson CC, Mandleco B, Olsen SF ym. Authoritative, Authoritarian, and Permissive Parenting Practices: Development of a New Measure. Psychol Rep 1995;77:819-830.) https://doi.org/10.2466/pr0.1995.77.3.819

(40) Baumrind D. Effects of authoritative parental control on child behavior. Child Dev 1966;37:887-907. https://doi.org/10.2307/1126611

(41) Kivijärvi S. Vanhemmuustyylit, vanhemmuuteen liittyvä stressi ja niiden väliset yhteydet pikkulapsiperheiden äideillä ja isillä. Pro gradu -tutkielma. Psykologian laitos, Jyväskylän yliopisto; 2007.

(42) Terry DJ. Parenting Stress Index Inventory. Kirjassa: Perlmutter BF, Touliatos J, Holden GW. Handbook of Family Measurement Techniques. Instruments \& Index Vol 3. California USA: Sage Publications; 2001, 470-471.

(43) Jokivuori P, Hietala R. Määrällisiä tarinoita: Monimuuttujamenetelmien käyttö ja tulkinta. Helsinki: WSOY Oppimateriaalit Oy; 2007.

(44) Sinai D, Tikotzky L. Infant sleep, parental sleep and parenting stress in families of mothers on maternity leave and in families of working mothers. Infant Behav Dev 2012;35:179-186. https://doi.org/10.1016/j.infbeh.2012.01.006

(45) Belísio AS, Louzada FM, Azevedo CVM. Influence of social factors on the sleep-wake cycle in children. Sleep Sci 2010;3:82-86.

(46) Gregory AM, Sadeh A. Sleep, emotional and behavioral difficulties in children and adolescents. Sleep Med Rev 2012;16:129-136. https://doi.org/10.1016/j.smrv.2011.03.007

\section{NiINA HÄKÄLÄ}

YTM, erikoissuunnittelija

Terveyden ja hyvinvoinnin laitos

\author{
PIRJO PÖLKKI \\ Emeritaprofessori, PsT \\ ybteiskuntatieteiden laitos \\ Itä-Suomen yliopisto
}

JUHA HÄMÄLÄINEN

Professori, YTT

ybteiskuntatieteiden laitos

Itä-Suomen yliopisto

TIINA PAUNIO

LTT, Psykiatrian professori

Helsingin yliopisto

ANNELI KylliäINEN

Yliopistonlehtori, PsT

Psykologia, Yhteiskuntatieteiden tiedekunta

Tampereen yliopisto

\section{Outi SAARENPÄÄ-HeIKKILÄ}

LT, lastenneurologian erik.lääk. ayl

Lastenneurologian yksikkö

Lastentautien klinikka

TAYS

\section{JuUlia PaAvonen}

LT, dos, VTK, vs. osastonlääkäri

HUS lastenpsykiatria ja Helsingin yliopisto

Erikoistutkija

Terveyden ja hyvinvoinnin laitos 